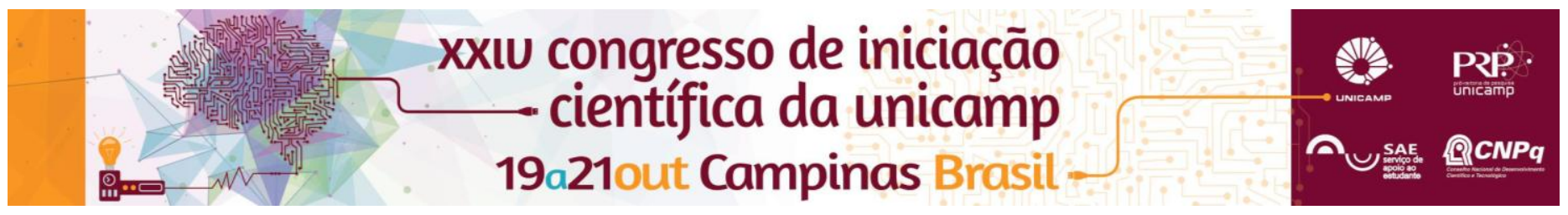

\title{
PETROGRAFIA E GEOQUÍMICA DOS ANFIBOLITOS DO EXTREMO LESTE DO COMPLEXO SANTA FILOMENA, FAIXA RIACHO DO PONTAL, PROVÍNCIA BORBOREMA
}

\author{
Rafael Bassetto Ferreira; Wagner da Silva Amaral*
}

\begin{abstract}
Resumo
A Faixa Riacho do Pontal localiza-se no nordeste do Brasil na Província Borborema e divide-se em três zonas: Interna, Central e Externa (de norte para sul, respectivamente). Deste modo, com foco no extremo leste da Faixa, especialmente na Zona Interna, obteve-se amostras de anfibolitos que ocorrem intercalados como lentes nos granada biotita xistos do Complexo Santa Filomena.Tais anfibolitos apresentaram uma associação mineral composta por Quartzo + Anfibólio + Plagioclásio + Clinopiroxênio + Titanita \pm Biotita \pm Rutilo, o que sugere metamorfismo em condições de Fácies Anfibolito. Dados geoquímicos de sete amostras de anfibolitos do extremo leste da Faixa, indicam protólitos correspondentes a basaltos alcalinos formados em ambiente transicional entre intraplaca e MORB.
\end{abstract}

\section{Palavras-chave:}

Petrografia, Geoquímica, Província Borborema

\section{Introdução}

A Faixa Riacho do Pontal (FRP) limita-se a norte pela zona de cisalhamento Pernambuco e a sul pelo Cráton São Francisco. Apresenta uma intensa atividade magmática, deformacional e metamórfica desenvolvida desde 0 Toniano (1000-960 Ma) até 0 Ediacarano/Cambriano ${ }^{1}$. É dividida em três zonas: A zona Interna, caracterizada por rochas metavulcanosedimentares, representada nos complexos Paulistana/Santa Filomena ${ }^{1}$. A Zona Central, representada pelo complexo Monte Orebe, onde predominam rochas com registros de crosta oceânica neoproterozóica ${ }^{2}$. E a Zona Externa, que é caracterizada por rochas metassedimentares de baixo grau metamórfico ${ }^{1}$. No extremo leste da FRP ocorrem lentes de rochas metamáficas (anfibolitos) associados à sequência metapelítica do Complexo Santa Filomena. Assim uma comparação em termos petrográficos e geoquímicos foi realizada no escopo deste trabalho, entre anfibolitos de diversas regiões da FRP, com objetivo de avaliar a natureza dos protólitos e seus ambientes geotectônicos de formação.

\section{Resultados e Discussão}

A partir de estudos petrográficos os anfibolitos foram caracterizados com a principal assembleia mineral: Quartzo+Anfibólio(Actinolita/Tremolita/Hornblenda)+Plagi oclásio+Diopsídio+Titanita \pm Biotita \pm Rutilo, Ainda há a Paragênese mineral em equilíbrio composta por $\mathrm{Qtz}+\mathrm{Anf}+\mathrm{Pl}+\mathrm{Ti}+\mathrm{Cpx}$, além de alguns minerais acessórios, como carbonato, epidoto, zircão e apatita(Fig.1a). A associação paragenética principal sugere um ápice do metamorfismo em condições de Fácies Anfibolito. Com relação a geoquímica, foi realizada uma comparação entre os dados desse projeto e os demais dados da literatura. De acordo com os diagramas elaborados no software GCDKit, as amostras analisadas neste trabalho correspondem a basaltos alcalinos (Fig.1b), formados predominantemente em ambientes transicional intraplaca e subordinadamente basaltos do tipo MORB (Fig.1c-d). O que se mostra contrária as amostras do Complexo Monte Orebe, e coerentes com os basaltos do Complexo Paulistana. a

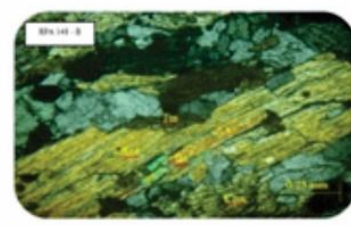

- Amostras Analisadas (2016) - Complexo Paulistana, Caxito (2013) - Monte Orebe. Caxito (2013) A. Monte Orebe. Folha Santa Filomena (1988) Complexo Santa Filomena, Fitho (20:9)

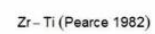
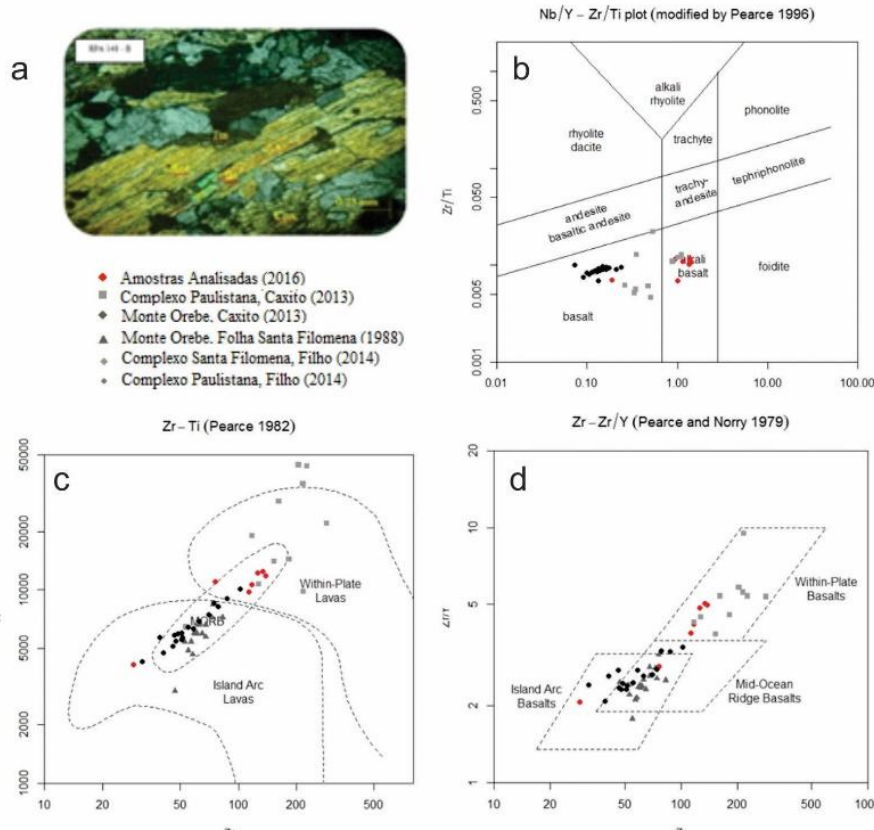

$\mathrm{Zr}-\mathrm{Zr} / \mathrm{Y}$ (Pearce and Norry 1979)

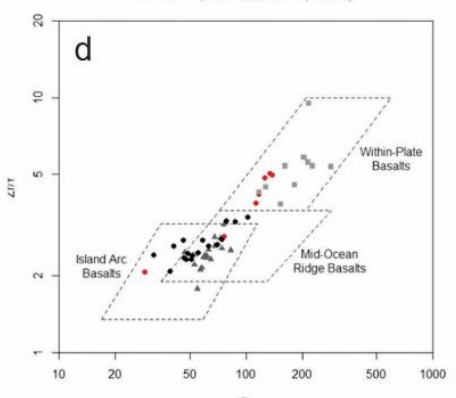

Figura 1.Fotomicrografia da lâmina RPA - 148B e Diagramas geoquímicos comparados com dados desse projeto e dados da literatura.

\section{Conclusões}

Conclui-se, que as rochas metamáficas estudadas no extremo leste da FRP apresentam paragêneses tanto de Fácies Xisto Verde como de Fácies Anfibolito. Dados geoquímicos mostraram afinidades com protólitos de basaltos alcalinos de ambientes intracontinentais com alguma contribuição oceânica. As rochas metamáficas dessa região refletem, portanto, uma semelhança com as rochas anfibolíticas pertencentes ao Complexo Paulistana e não com o Complexo Monte Orebe.

\section{Agradecimentos}

Ao Projeto FAPESP (2014/03275-3)

\footnotetext{
${ }^{1}$ Neves, B.B.B. Orogenias: das margens continentais ao interior remoto das placas, uma revisão do tema. Terrae Didática, 2015; 12(1); 19-55.

${ }^{2}$ Caxito, F.; Uhlein, A.; Stevenson, R.; Uhlein, G. J. Neoproterozoic oceanic crust remnants in northeast Brazil. Geology, 2014; 42; 387-390.
} 